\title{
JUDGING THE CASE IN THE ABSENCE OF THE DEFENDANT REMOVED FROM THE TRIAL ON GROUNDS OF DISCIPLINE
}

\author{
Arina lalanji*, ORCID ID: 0000-0002-3520-7197 \\ Technical University of Moldova,168, Ștefan cel Mare bd.,Chișinău, Republic of Moldova \\ *arina.ialanji@dp.utm.md
}

Received: 02. 22. 2021

Accepted: 04. 24. 2021

\begin{abstract}
The article analyzes the legal provisions governing the conditions of trial in the absence of the defendant if he is removed from the trial for disciplinary reasons by adjusting them to practical cases both at national level and in the jurisprudence of the European Court and by highlighting gaps in the national legislation in this regard. The researched topic is a current one since the compromising behavior of the defendant during the court hearings is attested more and more often, a fact that directly threatens the order and solemnity of the criminal trial, as well as the interests of the participants in the trial. The issue in question acquires an important connotation, including through the uneven practice applied by the courts on how to judge the case by removing the defendant from the trial, as well as the negative consequences that arise as a result - nullity of the judgment adopted, thus violating the principle of efficient administration of justice. Based on the obtained results, the legal omissions in the part related to the trial procedure in the absence of the defendant are revealed, the judicial errors admitted in practice in this respect, being elaborated preliminary versions for their solution, which can be used effectively for the application of legal provisions. versions for their solution. the activity of applying the legal provisions in practice.
\end{abstract}

Keywords: the right to be present at the trial, criminal trial, legal summons, removal of the defendant from the courtroom on grounds of discipline, trial of the case in the absence of the defendant, order and solemnity of the criminal trial.

Rezumat. Articolul analizează dispozițiile legale care reglementează condițiile procesului în absența inculpatului, dacă acesta este eliminat din proces din motive disciplinare, ajustându-le la cazurile practice atât la nivel național, cât și în jurisprudența Curții Europene, prin evidențierea lacune în legislația națională în acest sens. Subiectul cercetat este unul actual, întrucât comportamentul compromițător al inculpatului în timpul ședințelor de judecată este atestat din ce în ce mai des, fapt care amenință în mod direct ordinea și solemnitatea procesului penal, precum și interesele participanților la proces. Problema în cauză capătă o conotație importantă, inclusiv prin practica inegală aplicată de instanțe cu privire la modul de judecare a cauzei prin eliminarea inculpatului din proces, precum și consecințele negative care decurg ca urmare - nulitatea hotărârii adoptate, 
încălcând astfel principiul administrării eficiente a justiției. Pe baza rezultatelor obținute, se relevă omisiunile legale din partea legată de procedura de judecată în absența inculpatului, erorile judiciare admise în practică în acest sens, fiind elaborate versiuni preliminare pentru soluționarea acestora, care pot fi utilizate eficient pentru aplicarea prevederilor legale.

Cuvinte cheie: dreptul de a fi prezent la proces, proces penal, citarea legală, înlăturarea inculpatului din sală pe motiv de disciplină, judecarea cauzei în lipsa inculpatului, ordinea și solemnitatea procesului penal.

\section{Introducere}

Dreptul persoanei acuzate de a fi prezentă în persoană la proces este inclus în dreptul la un proces echitabil prevăzut la articolul 6 din Convenția Europeană Drepturilor Omului și a Libertăților Fundamentale [1].

Respectarea drepturilor omului rămâne piatra de temelie a unei societăți democratice și o condiție de acces în comunitatea internațională. Astfel, aspirațiile europene ale Republicii Moldova pot fi realizate doar respectând standardele consfințite și unanim recunoscute ale justiției. Îndeosebi, acest standard urmează a fi respectat în cadrul justiției penale, unde există în modul cel mai avansat riscul afectării drepturilor și libertăților.

Pe un loc deosebit printre principiile dreptului procesual penal se plasează principiul dreptului la un proces echitabil care garantează și dreptul persoanei acuzate în materie penală de a participa la propriul proces cunoscând toate piesele dosarului, raportat la înlăturarea acestuia din proces drept sancțiune pentru nerespectarea ordinii și solemnității.

Pe de altă parte, judecarea cauzei în lipsa inculpatului implică unele derogări de la normele generale ale procedurii penale, precum principiul contradictorialității și egalității armelor, creând astfel riscul afectării, în activitatea practică, a drepturilor procesuale. Prin urmare, asigurarea unei balanțe echitabile între realizarea scopurilor procesului penal și drepturile persoanei absente la procesul său constituie una din problemele fundamentale ale procesului penal contemporan. O importanță deosebită se acordă întrebării privind asigurarea pe parcursul procesului a drepturilor inculpatului absent. Cu toate acestea, având în vedere că scopul procesului penal implică și apărarea persoanei împotriva condamnării neîntemeiate și ilegale, apărarea drepturilor și libertăților participanților la proces, inclusiv a victimei, procedura judecării cauzei în lipsa inculpatului ar trebui să fie echilibrată, astfel încât urmează a fi cumulate interesele publice și interesele legitime ale persoanelor implicate în procesul penal.

\section{Metode şi materiale utilizate}

Studiul efectuat a avut la bază cercetarea legislației naționale în domeniul sancționării inculpatului ce nu respect ordinea și solemnitatea procesului penal. Pentru fundamentarea cercetării propuse, s-a utilizat, în principal următoarele metode de cercetare: - metoda cantitativă, cu ajutorul căreia am adunat, stocat și interpretat informaţ̧iile extrase din legislaţie, jurisprudenţă şi doctrina internă, dar şi cele aparţinând doctrinei şi jurisprudenţei internaţionale în materie; - metoda ştiinţifică, pentru prelucrarea logico-juridică a datelor obţinute prin metoda descrisă anterior, identificând problemele existente la momentul actual în legislaţia, jurisprudenţa şi doctrina națională; - metoda logică (analiza deductivă, inductivă, generalizarea - pentru examinarea și interpretarea cadrului legal și a materialului doctrinar); un accent aparte s-a pus pe utilizarea metodei 
empirice. În scopul realizării obiectivelor propuse, a fost studiată pe larg jurisprudența internă cât și a Curții Europene a Drepturilor Omului.

\section{Rezultatele obținute și discuții}

Legislația procesual penală a RM în art. 321 Cod de Procedură Penală [2], stabilește participarea obligatorie a inculpatului la proces, însă de la regula dată, potrivit legii interne, am putea distinge următoarea excepție admisibilă prin lege pentru judecarea cauzei în lipsa inculpatului:

- Este eliberat de la prezența în sală pe motiv de disciplină. Modalitatea dată de judecare a cauzei în lipsa inculpatului nu este stipulată în cadrul normei procesual penale ce reglementează participarea inculpatului la proces și condițiile legale pentru judecarea cauzei în lipsa acestuia. Putem conchide că, în fapt, aceasta implică o sancțiune ce se aplică inculpatului pentru nerespectarea ordinii și solemnității în proces din partea acestuia și a curma comportamentul abuziv al lui manifestat prin lipsa de respect față de instanță, fiind stipulată în norma legală ce reglementează măsurile care se iau faţă de cei ce încalcă ordinea şedinţei de judecată.

Art. 333 alin. (4) CPP prescrie că participanții la ședința de judecată sunt obligați să mențină ordinea în ședință. Reguli privind modul de comportament al participanților la proces și al altor persoane în cadrul instanțelor, precum și la ședința de judecată, inclusiv a inculpatului pot fi regăsite și în Regulile de conduită a justițiabililor și a altor persoane în instanța judecătorească, elaborate de către Consiliul Superior al Magistraturii, la pct. 14 - 15 [3].

În lucrarea sa, lg. Dolea indică că față de inculpat nu se aplică o altă sancțiune disciplinară decât atenționarea asupra necesității respectării disciplinei, care este mai mult o măsură de prevenție decât o sancțiune procesuală [4]. În dicționarul de drept procesual penal, îndepărtarea din sala de ședință este definită ca măsură ce poate fi luată de președintele completului de judecată în vederea asigurării ordinii și solemnității ședinței de judecată. Această măsură se dispune când una din părți sau oricare altă persoană în mod repetat și prin abateri grave tulbură ședința, cu toate că președintele i-a atras atenția să respecte disciplina [5].

În jurisprudența sa, Curtea Europeană a statuat că pentru buna administrare a justiției, ordinea și solemnitatea ședinței de judecată constituie elemente definitorii ale procedurii judiciare. Nerespectarea flagrantă de către inculpat a normelor elementare de conduită adecvată nu poate și nu trebuie să fie tolerată [6]. Potrivit art. 63 alin. (1) și (2) al Statutului Curții Penale Internaționale, se stabilește că, dacă acuzatul, prezent în fața Curții, tulbură continuu desfășurarea procesului, Camera de primă instanță poate ordona evacuarea acestuia din sala de ședință, având grijă ca acesta să urmărească procesul și să dea instrucțiuni avocatului său [7].

Alin. (2) al art. 334 CPP stabilește că, dacă inculpatul încalcă ordinea ședinței și nu se supune dispozițiilor președintelui ședinței, ultimul îi atrage atenția asupra necesității respectării disciplinei, iar în caz de repetare a încălcării ori de abatere gravă de la ordine, se dispune îndepărtarea lui din sala de judecată, continuând procesul în lipsa acestuia.

În atare condiții, legiuitorul reglementează modalitatea de aplicare a sancțiunilor procesuale pentru nerespectarea ordinii de către inculpat în ședința de judecată. Sancțiunile procedurale pot fi definite ca măsuri cu caracter de constrângere menite să garanteze respectarea normelor juridice care prescriu formele și condițiile de realizare a activității judiciare [8]. 
Respectiv, îndepărtarea inculpatului din sală constituie o sancțiune pentru nerespectarea ordinii procesului prin nesupunerea prevederilor legale și urmează a fi tratată ca o sancțiune datorată culpei acestuia. În atare condiții, instanța de judecată trebuie să acorde prioritate principiului oficialității și necesității înfăptuirii justiției, decât posibilității asigurării prezenței în persoană a inculpatului la proces și accesul liber la justiție, prin realizarea unor acțiuni de către acesta de împiedicare în desfășurarea justiției și lipsă de respect.

Temei pentru îndepărtarea inculpatului din sala de ședințe urmează să servească încălcarea repetată de către acesta a disciplinei și refuzului de a se supune deciziei instanței, cu condiția că anterior acesta a fost preîntâmpinat referitor la inacceptabilitatea unui astfel de comportament pe parcursul procesului și consecințele ce pot surveni. Un lucru destul de util ar fi emiterea unei încheieri motivate de îndepărtare a inculpatului de la proces ce poate fi contestată pentru a evita casarea sentinței, cum s-a stabilit în majoritatea spețelor cercetate în cadrul prezentei lucrări.

Astfel, în cauza Ananiev contra Rusiei, CtEDO a stabilit că refuzul aparent al inculpaților de a respecta principiile de bază ale bunei conduite nu poate și nu ar trebui permis. Curtea a acceptat că conduita reclamantului a fost de așa natură încât îndepărtarea sa din sala de judecată și continuarea ședinței fără prezența sa ar putea fi justificate. Însă, obligația președintelui era să determine dacă putea să prevadă în mod clar consecințele unui astfel de comportament [9].

Urmează a fi relevat că legislația diferențiază modalitatea de aplicare a sancțiunilor procesuale în funcție de subiectul culpabil pentru comiterea abaterii, astfel încât toți ceilalți pot fi supuși amenzii judiciare, cu excepția inculpatului care inițial urmează a fi atenționat pentru comportamentul său, după care, dacă continuă acțiunile sale, poate fi înlăturat de la proces.

În jurisprudența sa, Curtea Constituțională a statuat limitele legalității procesului echitabil prin prisma sintagmei de îndepărtare a inculpatului din sala de ședințe, continuând procesul în lipsa acestuia, în raport cu acțiunile acestuia, stabilind că dispozițiile articolului 334 alin. (2) din Codul de procedură penală permit instanței de judecată de a dispune îndepărtarea inculpatului din sala de judecată și să continue procesul în lipsa acestuia, dacă acesta încalcă ordinea ședinței și nu se supune dispozițiilor președintelui ședinței. Or, accesul liber la justiție constituie un aspect inerent al dreptului la un proces echitabil, cuprinzând mai multe relații și drepturi fundamentale. Exercitarea dreptului la un proces echitabil nu poate avea loc decât într-un anumit cadru juridic, stabilit de legiuitor, cu respectarea anumitor exigențe, de natură a preveni eventualele abuzuri și tergiversarea soluționării cauzelor deduse judecății [10].

Se observă că președintelui ședinței de judecată, având rolul de a asigura respectarea ordinii în ședința de judecată [art. 317 din Codul de procedură penală], îi revine sarcina de a explica ope legis inculpatului că este obligat să respecte ordinea stabilită în ședința de judecată, precum și că în eventualitatea unei desconsiderări a acestui imperativ poate fi îndepărtat din sala de judecată, asumându-și în acest sens consecințele juridice asupra dreptului de a participa la propriul proces. Respectiv, inculpatul poate să decidă până la aplicarea măsurii de îndepărtare din sala de judecată, în cunoștință de cauză, dacă dorește sau nu să beneficieze de dreptul său de a participa la propriul proces. Or, desconsiderând normele elementare de conduită corespunzătoare, inculpatul prin comportamentul său își exprimă fără echivoc voința de a nu participa la proces. Se atestă că din dispozițiile legale 
nu reiese că inculpatul va fi privat de dreptul său de a participa la judecarea cauzei pe tot parcursul procesului judiciar, or inculpatului, fiind îndepărtat din sala de judecată i se menține dreptul de a fi asistat și apărat în mod efectiv de un avocat ales de el sau numit din oficiu.

În același timp, având în vedere că pe parcursul judecării cauzei în primă instanță inculpatul poate fi îndepărtat de mai multe ori din sala de judecată pentru încălcarea ordinii ședinței de judecată, totuși se observă că dispozițiile art.334 alin.(2) din CPP stabilesc că sentința se va pronunța în prezența inculpatului sau se va aduce la cunoștința acestuia imediat după pronunțare, or, potrivit art.401 din CPP, inculpatul are dreptul să atace sentința cu apel în vederea unei noi judecări în fapt și în drept a cauzei. Potrivit jurisprudenței Curții Europene, procesul este echitabil dacă acuzatului i s-a permis să atace sentința de condamnare in absentia și a avut dreptul de a fi prezent la ședința instanței de apel [11].

Atunci când procedurile privesc numai chestiuni juridice, nu se poate ridica o problemă din refuzul de a-i permite acuzatului să fie prezent, alături de avocatul său. În cauza Kremzow contra Austriei, Curtea a constatat o încălcare atunci când reclamantul a fost exclus de la procesul de apel împotriva sentinței, fiind condamnat la închisoare pe viață într-o instituție specială. Deoarece evaluarea caracterului, stării de spirit și motivării reclamantului era importantă pentru proceduri, spiritul de echitate impunea ca acesta să participe la proceduri alături de avocatul său.

Inculpatul poate renunța la o audiere publică, dacă acest fapt se produce din libera sa voință și într-un mod lipsit de echivoc, totuși aceasta nu trebuie să se contrapună unui interes public important. În cauza Botten contra Norvegiei, Curtea a considerat că instanța superioară era obligată să ia măsuri concrete pentru a asigura prezența acestuia ca necesară pentru o evaluare adecvată [12].

Referitor la aplicarea prevederilor privind înlăturarea de la proces pentru motiv de disciplină, am putea menționa decizia Curții Supreme de Justiție în privința lui Ș.R., unde s-a stabilit că inculpatul a fost condamnat la 18 ani închisoare, fiind contestat actul judiciar. Referitor la argumentele precum că inculpatului i-a fost încălcat dreptul la apărare și dreptul la un proces echitabil, instanța de apel a indicat că RȘ a avut un comportament inadecvat în cadrul ședinței, iar, în scopul asigurării bunei funcționări a instanței și securității participanților la proces, instanța corect a dispus îndepărtarea lui din sala de judecată, cu continuarea procesului penal în lipsă, sentința fiindu-i adusă la cunoștință. Prin decizia sa, instanța ierarhic superioară a admis recursul cu remiterea cauzei la rejudecare, indicând că în prima instanță inculpatului i-a fost atrasă atenția să se supună dispozițiilor președintelui ședinței de judecată privind menținerea ordinii în ședință, iar, ulterior, pentru încălcarea repetată a ordinii, a fost îndepărtat din sala de ședințe pe parcursul judecării cauzei penale, cu pronunțarea sentinței în prezența acestuia.

S-a reținut că instanța de apel neîntemeiat a respins demersurile inculpatului RȘ privind audierea martorului și a unui specialist, odată ce inculpatul nu a participat la examinarea cauzei în prima instanță, fiind astfel încălcat dreptul inculpatului la un proces echitabil. Curtea a considerat că prima instanță a încălcat dreptul inculpatului de a participa efectiv la desfășurarea procesului penal, nefiind audiat în ședința de judecată, or, avocatul care reprezenta interesele inculpatului a solicitat audierea inculpatului pentru a nu încălca dreptul acestuia la un proces echitabil și principiul contradictorialității, însă instanța a refuzat demersul din motiv că inculpatul a fost îndepărtat din sala de judecată până la 
pronunțarea sentinței. La caz, prima instanță urma să concretizeze dacă inculpatul solicită reîntoarcerea în sală cu obligația de a nu mai încălca ordinea, cu atât mai mult că acesta ulterior îndepărtării din sala de judecată și până la pronunțarea sentinței a fost escortat în instanță, însă nu a fost dus în sala de ședințe [13].

Prin decizia Colegiului Penal al Curții de Apel Chișinău [14], a fost adoptată o nouă hotărâre la caz, drept motive fiind reținute argumentele în fapt și în drept a Curții Supreme de Justiție pe marginea ingerințelor admise la judecarea cauzei în lipsa inculpatului.

Considerăm opinia instanțelor superioare una corectă, din moment ce s-a constatat că la examinarea fondului inculpatul a realizat comportamentul nedisciplinar al său și pleda pentru participarea ulterioară la proces, stare ce urma, de fapt, a fi reținută de instanța de fond prin continuarea procesului în prezența inculpatului, reieșind din prevederile legale în domeniu. Din moment ce inculpatul este îndepărtat din sală pentru încălcarea ordinii, acesta dispune de dreptul legal de a cere revenirea în proces dacă a realizat caracterul nedemn al acțiunilor sale, or înlăturarea inculpatului de la proces în sine deja este o sancțiune ce se aplică acestuia, astfel nu poate fi suplimentar privat de dreptul de a administra și cere cercetarea probelor.

Legalitatea înlăturării de la proces pe motiv de încălcare a ordinii o putem releva din cauza penală de învinuire a lui $\mathrm{FI}$, unde instanța de fond a judecat cauza în lipsa inculpatului, reținând că, pe parcursul examinării cauzei, inculpatul de mai multe ori a fost înlăturat din sala ședinței de judecată, deoarece, după atenționarea acestuia asupra încălcărilor ordinii și disciplinei în ședință și asupra lipsei de respect de care dădea dovadă, fiind avertizat despre faptul că va fi înlăturat din sala ședinței, acesta nu se conforma indicațiilor instanței. Inculpatul, însă, a fost asistat de către doi avocați care i-au apărat interesele în lipsa acestuia. Instanța a reținut că în speța Marguš c. Croației, Curtea Europeană a conchis că eliminarea forțată a reclamantului din sala de ședințe în timpul audierii nu a încălcat dreptul acestuia la auto-apărare, ținând cont de faptul că însăși reclamantul a demonstrat un comportament incompatibil, fiind de două ori atenționat de către tribunal să se comporte adecvat [15]. Prin contestarea sentinței în cadrul recursului, inculpatul a invocat tergiversarea examinării cauzei penale, motive ce nu au fost reținute de instanța de apel, deoarece, după multiplele cereri de amânare a inculpatului, instanța a reluat cercetarea judecătorească pentru audierea inculpatului, care insista de a fi audiat, și cu admiterea acestuia în ședința de judecată după înlăturare în legătură cu comportamentul agresiv, încălcarea disciplinei și neconformării indicațiilor președintelui de ședință [16]. Astfel, a fost constatat că termenul îndelungat de judecare a cauzei se datorează comportamentului abuziv al inculpatului. În prezenta speță, observăm că inculpatului de mai multe ori i-a fost acordată posibilitatea de a participa la proces în urma îndepărtării sale de la ședință pe temei de disciplină, însă în rezultat acesta nu se reabilita, astfel fiind apreciată corectă soluția instanței privind judecarea cauzei în lipsa sa, prioritate având necesitatea înfăptuirii justiției și respectării drepturilor celorlalți participanți la proces.

\section{Concluzie:}

În concluzie, majoritatea cauzelor de judecare în lipsa inculpatului implică unele ingerințe în drepturile acestuia, din care motive de cele mai dese ori hotărârile judecătorești adoptate la caz sunt casate, astfel prin lege ar trebui stabilite reguli generale ce trebuie respectate de către instanțele judecătorești în cazul adoptării deciziei de examinare în lipsa inculpatului, pentru a evita implicarea unor ingerințe în drepturile victimelor referitoare la 
termenul rezonabil, precum și nerealizarea scopului legii procesual penale de înfăptuire a justiției și sancționării persoanelor culpabile în comiterea infracțiunilor.

În baza cercetării realizate am concluzionat că judecarea cauzei în lipsa inculpatului în cazul când acesta este îndepărtat de la proces se află în legătură cauzală directă cu comportamentul abuziv și agresiv al acestuia, care în mod intenționat induce la încălcarea ordinii în cadrul ședinței și manifestă lipsa de respect față de instanță și ceilalți participanți la proces, instanței de judecată revenindu-i obligația de aplicare corectă a prevederilor ce prescriu sancționarea acestuia prin privarea de dreptul participării la proces, care presupune că temei pentru îndepărtarea inculpatului din sala de ședințe urmează să servească încălcarea repetată de către acesta a disciplinei și refuzului de a se supune deciziei instanței, cu condiția că anterior acesta a fost preîntâmpinat referitor la inacceptabilitatea unui astfel de comportament pe parcursul procesului și consecințele ce pot surveni. Un lucru destul de util ar fi emiterea unei încheieri motivate de îndepărtare a inculpatului de la proces ce poate fi contestată pentru a evita ulterioare ingerințe în drepturile acestuia.

\section{Bibliografie}

1. Convenția Europeană a Drepturilor Omului, elaborată de Consiliul Europei, semnată la Roma pe 04 noiembrie 1950, ratificată de Republica Moldova prin Hotărârea Parlamentului nr.1298 din 24 iulie 1997

2. Codul de Procedură Penală al Republicii Moldova. În Monitorul Oficial al Republicii Moldova, 2003, nr. 104110.

3. Hotărârea CSM privind aprobarea Regulilor de conduită a justițiabililor și a altor persoane în instanța judecătorească, nr. 504/17 din 03 iunie 2014, în Monitorul Oficial, 2014, nr. 249-255/1241

4. Dolea I. Comentariu aplicativ al Codului de Procedură Penal. op.cit., p. 761.

5. Rusu V., Gavajuc S., Gheorghieș A., Gherasim D., Gherasim A., Rusu L. Dicționar de drept procesual penal. Chișinău: Pontos, 2012. - 248 p. ISBN 978-9975-51-351-7.

6. Ananyev vs Federația Rusă, nr. 20292/04, ECHR din 30 iulie 2009, par. 44. Disponibil: http://hudoc.echr.coe.int/eng?i=001-150432. [citat 12 septembrie 2016]

7. Statutul de la Roma al Curţii Penale Internaţionale, adoptat la 17 iulie 1998, ratificat de către RM prin Legea nr. 212 din 09.09.2010, în MO nr.190 la 29 septembrie 2010

8. Disponibil: https://legeaz.net/dictionar-juridic/sanctiuni-procedurale. @ 2018 LegeAZ.net. [citat 15 iunie 2018]

9. Ananyev vs Federația Rusă, nr. 20292/04, ECHR din 30 iulie 2009, par. 45-46. [citat 12 septembrie 2016] Disponibil:http://hudoc.echr.coe.int/eng?i=001-150432.

10. Decizia Curții Constituționale de inadmisibilitate a sesizării nr.16g/2017 privind excepția de neconstituționalitate a unor prevederi din articolul 334 alin.(2) din Codul de procedură penală al Republicii Moldova nr. 11 din 02 februarie 2017. Monitorul oficial al RM, 2017, nr. 181-189

11. Idalov vs Federația Rusă, nr. 5826/03, ECHR din 22 mai 2012, par. 171. [citat 28 martie 2018] Disponibil:http://hudoc.echr.coe.int/eng?i=001-182664.

12. Botten vs Norvegia, nr. 16206/90, ECHR din 19 februarie 1996, par.53. [citat 15 februarie 2017] Disponibil:http://hudoc.echr.coe.int/eng?i=001-57970.

13. Decizia Curții Supreme de Justiție din 13 decembrie 2016, nr. 1ra-1594/2016, în cauza penală de învinuire a lui Ș. Radu, Disponibil: http://jurisprudenta.csj.md/search_col_penal.php?id=7949

14. Decizia Colegiului Penal al Curții de Apel Chișinău din 23 noiembrie 2017, nr. 1a-213/17 privindu-l pe Ș Radu, Disponibil: https://cac.instante.justice.md/ro/pigd_integration/pdf/660a4d16-cdeb-e711-80d50050568 b7027

15. Cauza penală nr. 1-93/2013 de învinuire a lui FI în săvârșirea infracțiunii prevăzută la art. 155, 179 alin. (2), 189 alin. (3) lit. b) și art. 287 alin. (1) Cod Penal al RM, examinată de către Judecătoria Ungheni la 27 septembrie 2013, Disponibil: https://jun.instante.justice.md/ro/pigd_integration/pdf/35618e23-7427-e3119668-005056a5fb1a

16. Decizia Colegiului Penal al Curții Supreme de Justiție nr. 1ra-872/2015 din 11 august 2015 privind examinarea recursului lui $\mathrm{Fl}$ și avocatului acestuia, Disponibil: http://jurisprudenta.csj.md/search_col_penal.php?id=4752 